


\section{Antihagelkanonnen in de fruitteelt in de gemeente Borsele}

Piet Rijk

Dit onderzoek is uitgevoerd door Wageningen Economic Research in opdracht van en gefinancierd door de ZLTO.

Wageningen Economic Research

Wageningen, februari 2017

NOTA

2017-034 
Rijk, P., 2017. Antihagelkanonnen in de fruitteelt in de gemeente Borsele. Wageningen, Wageningen Economic Research, Nota 2017-034. 28 blz.; 0 fig.; 8 tab.; 0 ref.

Dit rapport is gratis te downloaden op https:// doi.org/10.18174/423593 of op www. wur. nl/economic-research (onder Wageningen Economic Research publicaties).

(C) 2017 Wageningen Economic Research

Postbus 29703, 2502 LS Den Haag, T 07033583 30, E communications.ssg@wur. nl, www. wur. nl/economic-research. Wageningen Economic Research is onderdeel van Wageningen University \& Research.

\section{(cc) BY-NC}

Wageningen Economic Research hanteert voor haar rapporten een Creative Commons Naamsvermelding 3.0 Nederland licentie.

(C) Wageningen Economic Research, onderdeel van Stichting Wageningen Research, 2017 De gebruiker mag het werk kopiëren, verspreiden en doorgeven en afgeleide werken maken. Materiaal van derden waarvan in het werk gebruik is gemaakt en waarop intellectuele eigendomsrechten berusten, mogen niet zonder voorafgaande toestemming van derden gebruikt worden. De gebruiker dient bij het werk de door de maker of de licentiegever aangegeven naam te vermelden, maar niet zodanig dat de indruk gewekt wordt dat zij daarmee instemmen met het werk van de gebruiker of het gebruik van het werk. De gebruiker mag het werk niet voor commerciële doeleinden gebruiken.

Wageningen Economic Research aanvaardt geen aansprakelijkheid voor eventuele schade voortvloeiend uit het gebruik van de resultaten van dit onderzoek of de toepassing van de adviezen.

Wageningen Economic Research is ISO 9001:2008 gecertificeerd.

Wageningen Economic Research Nota 2017-034 | Projectcode 2282700272

Foto omslag: Ellen Smits-Filius 


\section{Inhoud}

$\begin{array}{ll}\text { Woord vooraf } & 5\end{array}$

$\begin{array}{ll}\text { Samenvatting } & 6\end{array}$

S.1 Fruitbedrijven met een antihagelkanon $\quad 6$

S.2 Fruitteelt in de gemeente Borsele $\quad 6$

$\begin{array}{lll}\text { S.3 } & \text { Resultaten interviews } & 7\end{array}$

S.4 Methode $\quad 8$

$\begin{array}{llr}1 & \text { Inleiding } & 9\end{array}$

$\begin{array}{lll}1.1 & \text { Achtergrond } & 9\end{array}$

1.2 Onderzoeksvragen $\quad 9$

$\begin{array}{lll}1.3 & \text { Aanpak onderzoek/advies } & 10\end{array}$

3.2 Ontwikkeling aantal bedrijven, bedrijfsoppervlakte en bedrijfsomzet 12

$\begin{array}{lll}3.3 & \text { Bedrijfseconomische situatie (landelijk) } & 13\end{array}$

$\begin{array}{lll}3.4 & \text { Multiplier (spin-offeffecten) (landelijk) } & 15\end{array}$

3.5 Bedrijfseconomische situatie (gemeente Borsele) 15

4 Economisch belang fruitteeltbedrijven met een antihagelkanon 17

$\begin{array}{llr}5 & \text { Economische impact van een hagelbui } & 19\end{array}$

$\begin{array}{llr}6 & \text { Resultaten interviews } & 20\end{array}$

$\begin{array}{llr}7 & \text { Slotbeschouwing } & 24\end{array}$

Bijlage 1 Momentopname van de onweersbui van 28 augustus 2016, 6.53 uur 


\section{Woord vooraf}

In de gemeente Borsele hebben 23 fruittelers 9 antihagelkanonnen opgesteld ter voorkoming van hagelschade aan hun appels en peren tijdens onweersbuien. De meeste antihagelkanonnen zijn geplaatst in 2007. Voor de antihagelkanonnen is een omgevingsvergunning afgegeven door de gemeente Borsele. Op dit moment loopt er tegen deze vergunning een hogerberoepprocedure bij de Raad van State.

De groep fruittelers met een antihagelkanon heeft aan Wageningen Economic Research gevraagd om meer inzicht te geven in het economische belang van hun bedrijven en in die van de hele fruitteeltsector in de gemeente Borsele. Ook is gevraagd om de ervaringen van de fruittelers met de inzet van het antihagelkanon in beeld te brengen en aan te geven wat de impact van hagelschade is op de bedrijven. De ZLTO heeft, als opdrachtgever voor dit onderzoek, aan Wageningen Economic Research gevraagd om dit te doen.

Deze nota gaat in op deze onderzoeksvragen. De conceptversie van het onderzoek is op 25 januari 2017 besproken met:

- Mr. Marc (M.J.C.) Mol (juridisch medewerker Omgeving en Samenleving, ZLTO)

- Dhr. Rinus (M.A.) van 't Westeinde (regio-coördinator fruitteelt van de ZLTO)

- alle aanwezige fruittelers met een antihagelkanon.

Het onderzoek is uitgevoerd door Ir. P.J. (Piet) Rijk (projectleider). Verder hebben aan dit onderzoek meegewerkt Ing. J. (Jakob) Jager (regionale data), Ir. R.W. (Ruud) van der Meer (bedrijfseconomische data fruitteelt) en Drs. Ing. D.A. (David) Verhoog (multiplier fruitteeltsector). De review van de nota is gedaan door Dr. Ir. S. (Stijn) Reinhard en Dr. Ir. V. (Volkert) Beekman. Allen zijn werkzaam bij Wageningen Economic Research.

In het onderzoek zijn bijna alle fruittelers die een antihagelkanon hebben geïnterviewd. Ik wil hen bedanken voor hun bereidwillige medewerking.

Het resultaat van dit onderzoek zal bijdragen aan de kwaliteit van de besluitvorming over het gebruik van de antihagelkanonnen.

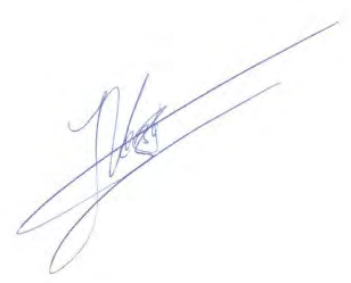

Prof.dr.ir. J.G.A.J . (Jack) van der Vorst Algemeen Directeur Social Sciences Group Wageningen University \& Research 


\section{Samenvatting}

\section{S.1 Fruitbedrijven met een antihagelkanon}

Structuur van de bedrijven

In het studiegebied zijn 9 antihagelkanonnen aanwezig die door 23 fruitbedrijven gebruikt worden. Meestal zijn 3 of 4 bedrijven betrokken bij 1 kanon (gedeeld eigendom), maar soms heeft ook een enkel bedrijf 1 kanon of hebben 2 bedrijven 1 kanon.

De bedrijven met een antihagelkanon hebben een totale gezamenlijke bedrijfsoppervlakte van 715 ha (gemiddeld 31 ha). Hiervan is 485 ha fruit (gemiddeld 21 ha fruit; 11 ha peren en 10 ha appels). De bedrijven zijn gemiddeld groter dan het gemiddelde fruitbedrijf in Borsele (17 ha) en landelijk (11 ha). Op de fruitbedrijven met een antihagelkanon is werkgelegenheid van totaal 126 arbeidsjaren, waarvan 56 regulier en 70 omgerekende arbeidsjaren los personeel (voornamelijk voor het plukken van het fruit). Samen met de indirecte werkgelegenheid (toelevering, verwerking, distributie, etc.) komt de werkgelegenheid uit op 200 arbeidsjaren.

\section{Bedrijfsomzetten en inkomens}

De bedrijven met een antihagelkanon halen samen een gemiddelde bruto-opbrengst van ongeveer $10 \mathrm{mln}$. euro per jaar. Dit komt neer op een gemiddelde bedrijfsomzet van $€ 435.000$ per bedrijf per jaar. Hiermee wordt gemiddeld $€ 69.700$ per bedrijf aan arbeidsinkomen door de regulier werkzame arbeidskrachten verdiend. Dit komt neer op $€ 28.600$ per arbeidskracht $(2,43$ arbeidskracht per bedrijf). Aan lonen voor los personeel wordt gemiddeld $€ 91.300$ per bedrijf uitgegeven (voor omgerekend 3,04 arbeidsjaareenheden).

Totaal wordt er op de bedrijven voor 3,7 mln. aan arbeidsinkomen verdiend (1,6 mln. voor de gezinnen en 2,1 $\mathrm{m} / \mathrm{n}$. door los personeel). In het samenhangende indirecte fruitcomplex (toelevering, verwerking en distributie) wordt circa $2 \mathrm{mln}$. euro aan inkomen verdiend, zodat het totale verdiende arbeidsinkomen dat met de bedrijven met een antihagelkanon samenhangt berekend wordt op $5,7 \mathrm{mln}$. euro per jaar.

\section{S.2 Fruitteelt in de gemeente Borsele}

In de gemeente Borsele zijn 80 fruitbedrijven; hiervan heeft bijna 30\% een antihagelkanon (23 bedrijven). Ook akkerbouwbedrijven hebben soms fruit. Het totale areaal fruit in de gemeente Borsele bedraagt bijna 1.700 ha (2015). Dit is een zesde van het totale door de land- en tuinbouw gebruikte grond in de gemeente Borsele. Het totale areaal appels en peren is bijna 1.400 ha appels en peren. Hiervan hebben de bedrijven met een antihagelkanon ruim een derde (475 ha). Het overige fruitareaal in de gemeente Borsele betreft vooral zwarte bessen (machinaal geoogst).

Het totale areaal appels en peren in de gemeente Borsele is de afgelopen 10 jaar met ruim 300 ha toegenomen. Een redelijk deel van het totale Nederlandse areaal appels en peren bevindt zich momenteel in de gemeente: voor appels is dit $7 \%$ en voor peren ruim $9 \%$. De afgelopen tien jaren is dit aandeel binnen Nederland toegenomen: in 2005 was dit respectievelijk 6 en 7\%.

In de gemeente Borsele is de directe werkgelegenheid op de fruitbedrijven 389 arbeidsjaren. Aan indirecte werkgelegenheid (toelevering, verwerking, distributie) rondom de fruitteeltsector in Borsele zijn er 233 arbeidsjaren betrokken, zodat het totale aantal arbeidsjaren voor het hele fruitcomplex voor Borsele uitkomt op 622 arbeidsjaren, waarvan een derde toe te rekenen is aan de fruitbedrijven met een antihagelkanon. 


\section{Bedrijfsomzetten en inkomens}

De totale brutobedrijfsomzetten voor de appel- en perenteelt in de gemeente Borsele bedragen circa $30 \mathrm{mln}$. euro per jaar. De directe verdiende inkomens in de gemeente Borsele in de fruitsector zijn berekend op $13 \mathrm{mln}$. euro; $6 \mathrm{mln}$. voor de ondernemers en $7 \mathrm{mln}$. voor de plukkers en ander los personeel. Samen met de indirect behaalde inkomens van het fruitcomplex (totaal bijna $7 \mathrm{mln}$. euro) worden de totaal verdiende inkomens van het samenhangende totale fruitcomplex voor de gemeente Borsele berekend op $20 \mathrm{~m} / \mathrm{n}$. euro per jaar.

\section{S.3 Resultaten interviews}

Fruittelers ervaren een positieve werking van de antihagelkanonnen en zijn ervan overtuigd dat het antihagelkanon hagelschade voorkomt en beperkt. Door de inslag van hagelkorrels in het groeiseizoen (april-oktober) op appels en peren komen er butsen en plekken op het dan hangende fruit. Dit maakt het fruit voor de consument onverkoopbaar.

In de jaren voor de plaatsing van de kanonnen in 2007 had men naar eigen zeggen regelmatig hagelschade. In de jaren daarna is dit beperkt geweest. Als men al schade had, dan was dit dikwijls aan de rand van de werkingssfeer van het kanon. Dit wordt nog eens bevestigd doordat bedrijven met een antihagelkanon soms percelen hebben liggen buiten de directe werkingssfeer van het antihagelkanon, waar wel soms aanzienlijke schade is. De werking is ongeveer een cirkel met een straal van 500 meter (ongeveer $78 \mathrm{ha}$ ). Maar door wind is het dikwijls geen echte cirkel maar een eivorm.

Een derde van de bedrijven heeft naar eigen zeggen geen schade gehad de afgelopen tien jaar. De andere bedrijven hadden beperkt schade, voornamelijk aan de randen van het werkingsgebied van het kanon. Een enkele keer was er hagelschade doordat het kanon te laat aangezet was of omdat de bui ineens van richting veranderde.

Opvallend is verder dat er verschillende keren op de site 'realtimelightning' ${ }^{1}$ is geconstateerd dat onweersbuien die vanuit Noord-Frankrijk over België naar Noord-Holland trokken, geen lichtflitsactiviteiten vertoonden boven de gemeente Borsele en in de rest van deze strook wel. De opnamen bevestigen volgens de geïnterviewde fruittelers dat dit door het gebruik van de antihagelkanonnen komt. Van deze beelden zijn ook opnamen gemaakt en bewaard. In bijlage 1 bij deze nota is een opname hiervan weergegeven.

Veel bedrijven met een antihagelkanon hebben de afgelopen jaren hun bedrijfsoppervlakte fruit uitgebreid. Zij zien de toekomst van de fruitteelt op hun bedrijf positief tegemoet. Veel bedrijfshoofden zijn nog relatief jong en de oudere bedrijfshoofden hebben vrijwel allemaal een bedrijfsopvolger. Voor de continuïteit van de fruitbedrijven is het verminderen en vermijden van bedrijfsrisico's belangrijk. Men wil zo veel mogelijk hagelschade zien te voorkomen op zijn bedrijf. Hierbij vinden de fruittelers het antihagelkanon een belangrijk middel dat men ook voor de toekomst behouden wil.

De schade die hagelbuien aanrichten op bedrijfsniveau kunnen oplopen tot vele tienduizenden euro's. Als een heel bedrijf getroffen wordt kan dit verlies oplopen tot meer dan honderdduizend euro per bedrijf.

1 https://www. lightningmaps.org 


\section{S.4 Methode}

Informatie van de fruittelers

In het gebied staan 9 antihagelkanonnen. Naast inzicht in de bedrijfseconomische situatie zijn bij de betrokken fruittelers van 6 antihagelkanonnen interviews gehouden. Hierbij waren 19 van de in totaal 23 bedrijven betrokken. Van hen is aanvullende informatie verzameld rond de door hen ervaren werking en effecten van het gebruik van het antihagelkanon. Verder zijn bij deze 23 fruitbedrijven de belangrijkste bedrijfsgegevens verzameld.

Andere bronnen en analyses

- Gegevens van de CBS landbouwtelling voor de gemeente Borsele en landelijke data, die door Wageningen Economic Research bewerkt zijn.

- Het Bedrijveninformatienet fruitteeltbedrijven van Wageningen Economic Research; deze steekproef van 36 fruitbedrijven geeft een representatief beeld van de bedrijfseconomische situatie van de Nederlandse fruitbedrijven. Deze gegevens zijn vergeleken met de situatie in de gemeente Borsele en met de groep fruitbedrijven met een antihagelkanon.

- $\mathrm{Er}$ is voor de indirecte werkgelegenheid (toelevering, verwerking, distributie, enzovoort) die samenhangt met de primaire werkgelegenheid in de fruitteelt een recente multiplier berekend voor de inkomens en werkgelegenheid, zodat dit van het gehele fruitcomplex een beeld geeft. 


\section{$1 \quad$ Inleiding}

\subsection{Achtergrond}

In de gemeente Borsele hebben fruittelers 9 antihagelkanonnen opgesteld ter voorkoming van hagelschade aan hun appels en peren tijdens onweersbuien. Soms heeft een individuele teler 1 kanon, maar dikwijls wordt samengewerkt om de kosten van het kanon te drukken (gedeeld eigendom). In totaal zijn er 23 fruittelers bij deze 9 antihagelkanonnen betrokken. De eerste kanonnen zijn tien jaar geleden geplaatst. Hiervoor is ook een omgevingsvergunning afgegeven door de gemeente Borsele. ${ }^{2}$ In heel Nederland staan er 17 antihagelkanonnen en in België 62 (informatie afkomstig van de betrokken fruittelers).

De aanschafkosten van een kanon bedragen ongeveer $€ 40.000$ en de exploitatiekosten ongeveer $€ 1.000$ à $€ 1.500$ per jaar. De werking van het kanon is dat als er een onweersbui aankomt op tijd begonnen wordt met elke zeven seconden een harde klap, zodat er een schokgolf in de richting van de dreigende bui gaat. Het apparaat dient 20 minuten tot een halfuur voordat de bui aankomt aangezet te worden. De theorie is dat deze drukgolf ervoor zorgt dat er geen of weinig hagelkorreltjes kunnen ontstaan en dat de zeer kleine hagelkorrels zich niet verder kunnen vergroten tot grotere hagelkorrels of hagelstenen; de aangroei van een korrel vindt geleidelijk plaats door op- en neergaande bewegingen in de lucht van een beginnende korrel. Door drukgolven in de lucht zou deze aangroeiing niet of minder plaatsvinden. Door de drukgolven wordt de warmere lucht onder in een zich ontwikkelende onweersbui gemengd met de koudere bovenlucht. Zo zou dit de hagelschade aan het fruitgewas kunnen wegnemen of verkleinen. Gemiddeld wordt een kanon ongeveer in totaal 6 uur gebruikt per jaar (4-8 uur per jaar).

Omdat de inzet van de kanonnen gepaard gaat met harde klappen heeft de Stichting tot Behoud van de Zak van Zuid Beveland tegen de vergunningsverlening bezwaar aangetekend bij de rechtbank. Dit in verband met schade aan de natuur. De rechtbank heeft de Stichting in haar vonnis gelijk gegeven en vindt dat de negen omgevingsvergunningen moeten worden ingetrokken. Op dit moment loopt er een hogerberoepprocedure bij de Raad van State. Deze heeft voorlopig voor 2016 aangegeven dat de antihagelkanonnen mogen worden gebruikt.

\subsection{Onderzoeksvragen}

De ZLTO heeft aan Wageningen Economic Research gevraagd te onderzoeken:

a. wat het economische belang is van de totale fruitteeltsector (en aanverwante sectoren, multiplier) in de gemeente Borsele (bruto-opbrengsten, inkomens-indicatief, werkgelegenheid). Ook meegenomen worden de effecten (indicatief) van de fruitteelt op andere sectoren (toerisme en dergelijke)

b. wat het economisch belang is van de bedrijven die een antihagelkanon hebben (gezamenlijk)

c. welke schade er is als een bedrijf getroffen wordt door hagel (kosten zijn wel gemaakt, opbrengsten zijn er bijna niet).

Verder wordt in kaart gebracht of de bedrijven die de afgelopen jaren antihagelkanonnen hebben gebruikt minder hagelschade hebben gehad dan de bedrijven die dit niet hebben. Bij de verdere concretisering van deze vraag bleek hiervoor een nauwkeurig onderzoek nodig. Het beschikbare budget was hiervoor niet toereikend. Om inzicht te krijgen in de werking en de effecten van het antihagelkanon is besloten om de betrokken fruittelers te interviewen, waarbij gevraagd is naar hun ervaringen met het antihagelkanon.

2 Tien jaar geleden was er nog geen omgevingsvergunning. Daarom is steeds - bij gebrek aan een correct wettelijk kader een legale vorm geprobeerd te vinden: milieuvergunning, ontheffing APV, melding met maatwerkvoorschriften. 


\subsection{Aanpak onderzoek/advies}

\section{Economische aspecten}

a. Het economische belang van de totale fruitteeltsector (en aanverwante sectoren, multiplier) in de gemeente Borsele (bruto-opbrengsten, inkomens, werkgelegenheid) is in kaart gebracht. Hierbij is gebruik gemaakt van de meest recente data van de afgelopen jaren uit het Bedrijveninformatienet (steekproef van 36 fruitbedrijven), de CBS landbouwtelling en andere aanwezige expertise die bij Wageningen Economic Research beschikbaar is. Met behulp van deze landelijk genormaliseerde data en de gegevens van de fruitbedrijven in de gemeente Borsele is een zo reëel mogelijk beeld geschetst van de situatie in de gemeente Borsele.

Ook is aandacht (kwalitatief en indicatief) gegeven aan eventueel positieve effecten van de fruitteelt op andere sectoren (toerisme en dergelijke).

b. Het economisch belang van de bedrijven die een antihagelkanon hebben (gezamenlijk) is bepaald op basis van een weergave door de individuele kanongebruikers van hoeveel ha appels, peren en eventueel ander fruit er in de nabijheid ligt van een kanon. Bij de bepaling van het economisch belang is gebruik gemaakt van gestandaardiseerde opbrengsten/kosten op basis van informatie uit het Bedrijveninformatienet.

c. Voor het bepalen van de schade als een bedrijf getroffen wordt door hagel zijn enkele scenario's geschetst, zoals wat de consequenties zijn als de fruitopstand volledig verhageld en wat de gevolgen zijn als delen van de fruitopstand verhagelen.

Effect en werking antihagelkanon

Dit is kwalitatief in beeld gebracht op basis van 6 interviews bij de groep fruittelers in Borsele die een antihagelkanon hebben (totaal bij 19 fruittelers). Hen is gevraagd naar hun ervaringen met hagelschade: Is er volgens hen minder schade dan vroeger? De verslaglegging hiervan in de nota is kwalitatief wat een duiding geeft van wat de telers met een antihagelkanon zelf ervaren hebben. Het geeft een indruk gebaseerd op de mening van de telers. Kwantitatieve data voor het uitvoeren van een dergelijke analyse zijn niet beschikbaar. 


\section{Structuur bedrijven met een antihagelkanon}

In het studiegebied zijn 9 antihagelkanonnen aanwezig die door 23 fruitbedrijven gebruikt worden. Meestal zijn er 3 of 4 bedrijven betrokken bij 1 kanon, maar soms heeft ook een enkel bedrijf 1 kanon of hebben 2 bedrijven 1 kanon. De 23 fruitbedrijven met een antihagelkanon hebben een totale bedrijfsoppervlakte van 715 ha (gemiddeld 31 ha). Hiervan is 485 ha fruit. Dit is gemiddeld 21 ha fruit per bedrijf (bijna 11 ha peren en 10 ha appels). In tabel 2.1 is een en ander nader weergegeven.

Zeven bedrijven hebben naast fruit ook andere gewassen (meestal akkerbouw). Van deze 485 ha fruit ligt 453 ha in de werkingssfeer van een antihagelkanon. Elders buiten de werking van een hagelkanon ligt 32 ha fruitteelt. Dit betreft drie bedrijven; ze hebben een deel van hun bedrijfsareaal fruit buiten de werkingssfeer van een antihagelkanon liggen.

De bedrijven zijn met ruim 21 ha gemiddeld groter dan het gemiddelde fruitbedrijf in de gemeente Borsele (16,5 ha in 2015; zie tabel 3.2 in deze nota) en Nederland (11,4 ha). Ook werken er gemiddeld meer mensen op de bedrijven; omgerekend (inclusief losse arbeid) 5,5 arbeidsjaareenheden tegenover circa 3,9 in Borsele en circa 4,2 in Nederland.

Gemiddeld zijn er op de bedrijven met een antihagelkanon 2,4 mensen regelmatig meer dan 19 uur per week werkzaam; dit is meestal gezinsarbeid met meestal langere werkweken dan 40 uur. In de gehele gemeente Borsele is dit gemiddeld 1,9 en landelijk 2,2. Op de bedrijven met een antihagelkanon zijn dus meer vaste arbeidskrachten werkzaam dan elders.

De bedrijfseconomische en inkomenssituatie op de bedrijven komen in hoofdstuk 4 aan de orde.

Tabel 2.1 Enkele kenmerken van de fruitbedrijven met een antihagelkanon in de gemeente Borsele in november 2016

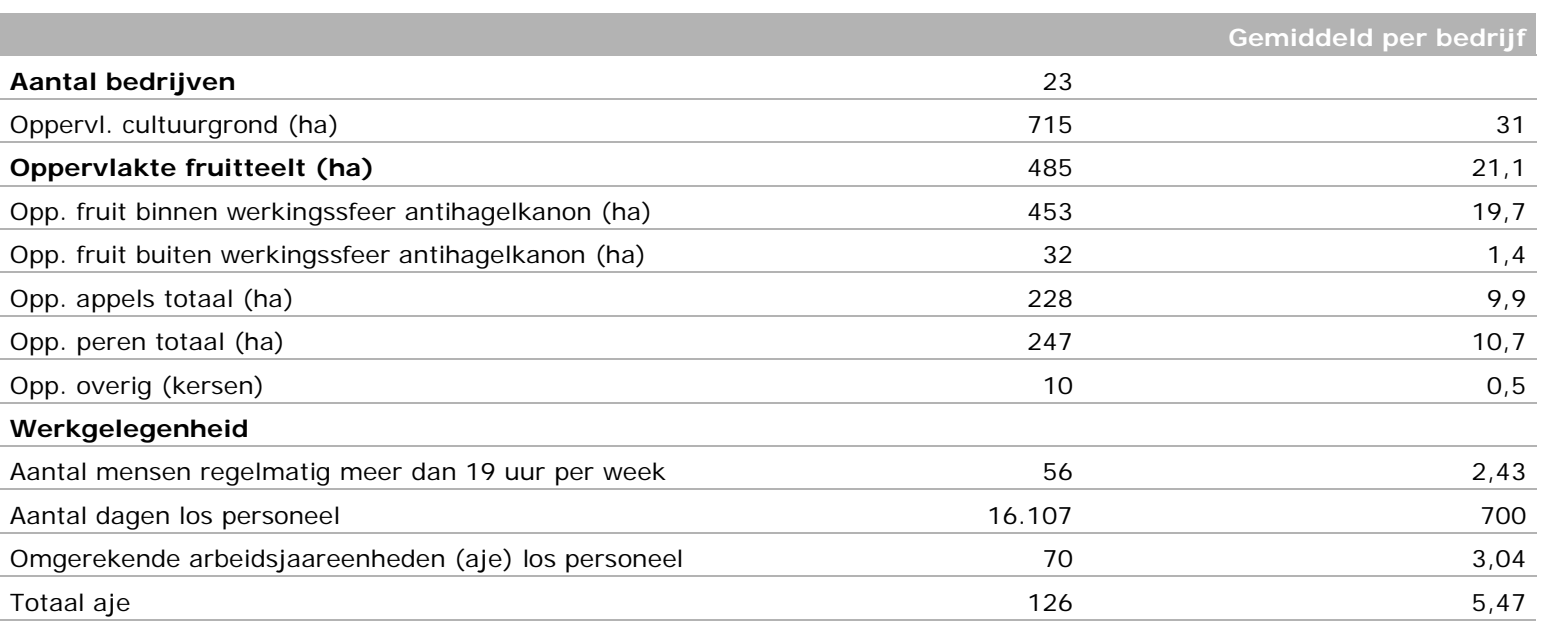

Bron: inventarisatie bij de bedrijven, november 2016. 


\section{Economisch belang fruitteeltsector Borsele en Nederland}

\subsection{Areaalontwikkeling}

De fruitteeltsector is een belangrijke sector in de gemeente Borsele, zowel voor het grondgebruik, de werkgelegenheid als de inkomens. Dit belang is ook de afgelopen jaren toegenomen. De totale oppervlakte appels en peren nam de afgelopen tien jaar met ruim 300 ha toe. In 2005 was bijna 13\% van het totale grondgebruik in de gemeente Borsele fruitteelt. In 2015 was dit toegenomen tot bijna $16 \%$ (tabel 3.1). Van het totale areaal fruit in Nederland (totaal bijna 19.800 ha) ligt nu bijna 1.700 ha in de gemeente Borsele; dit is ruim $8 \%$. Voor appels ligt dit op $7 \%$ en voor peren op ruim $9 \%$. Er heeft de afgelopen jaren een omslag plaats gevonden van minder appels naar meer peren. Ook landelijk was dit het geval, maar minder dan in Borsele. Dat het areaal appels en peren de afgelopen jaren toegenomen is heeft vermoedelijk te maken met relatief gunstige weersomstandigheden: het water van de Westerschelde is dichtbij en er is daardoor minder nachtvorst in de bloeiperiode in het voorjaar; er bevriezen minder bloesems dan elders.

Tabel 3.1 Agrarisch grondgebruik in de gemeente Borsele in 2005 en 2015 en de ontwikkeling daarvan in Borsele en Nederland

\begin{tabular}{|c|c|c|c|c|}
\hline & Borsele & Borsele & Borsele & Nederland \\
\hline & 2005 & 2015 & 2005-2015 & 2005-2015 \\
\hline Tot. opp. land- en tuinbouwgrond (ha) & 11.297 & 10.708 & $-5 \%$ & $-3 \%$ \\
\hline Ander fruit (ha) & 348 & 287 & $-18 \%$ & $+37 \%$ \\
\hline Tot. fruit (ha) & 1.422 & 1.668 & $+17 \%$ & $+6 \%$ \\
\hline$\%$ fruit van Nederland & $7,7 \%$ & $8,4 \%$ & & \\
\hline$\%$ appels en peren v. Ned. & $6,5 \%$ & $8,4 \%$ & & \\
\hline Appels (ha) & 592 & 523 & $-12 \%$ & $-22 \%$ \\
\hline$\%$ appels van Nederland & $6,1 \%$ & $6,9 \%$ & & \\
\hline
\end{tabular}

Bron: CBS-landbouwtelling, bewerking Wageningen Economic Research.

Naast appels en peren werd er in 2015 ook nog op 287 ha klein fruit geteeld. Dit zijn vooral machinaal geoogste zwarte bessen ( 256 ha, waarvan 60 ha op gespecialiseerde fruitbedrijven). Verder is er ander klein fruit ( 14 ha, vooral rode bessen, bramen en frambozen). Het overige areaal is kersen en pruimen. Omdat het antihagelkanon op dit moment alleen gebruikt wordt in de buurt van appel- en perenboomgaarden ligt het accent in deze nota liggen op de economische aspecten van de bedrijven met appels en peren.

\subsection{Ontwikkeling aantal bedrijven, bedrijfsoppervlakte en bedrijfsomzet}

Ruim een derde van alle land- en tuinbouwbedrijven in Borsele heeft fruit. Gespecialiseerde fruitbedrijven maken een kwart uit van de bedrijven in Borsele (tabel 3.2). In vergelijking met de rest van het land vermindert zowel het totaal aantal land- en tuinbouwbedrijven als het aantal gespecialiseerde fruitbedrijven in Borsele minder dan elders; de laatste 10 jaar met 10\% tegenover landelijk 20\%. De fruitbedrijven in Borsele zijn doorgaans ook groter dan landelijk het geval is. Dit 
komt zowel naar voren door een grotere bedrijfsoppervlakte als door gemiddeld hogere brutostandaardopbrengsten. Deze standaardopbrengst is een indicatie voor de omzet in euro's voor het bedrijf (om het inkomen te bepalen moeten alle bedrijfskosten nog afgetrokken worden).

Tabel 3.2 Aantal bedrijven, oppervlakte fruit per fruitbedrijf, en brutostandaardopbrengsten in de gemeente Borsele in 2005 en 2015 en de ontwikkeling daarvan in Borsele en Nederland

\begin{tabular}{|c|c|c|c|c|}
\hline & Borsele & Borsele & Borsele & Nederland \\
\hline Tot. aantal bedrijven & 385 & 325 & $-16 \%$ & $-22 \%$ \\
\hline Bedrijven met fruit (aantal) & 124 & 118 & $-5 \%$ & $-16 \%$ \\
\hline Aantal fruitbedrijven a) & 89 & 80 & $-10 \%$ & $-20 \%$ \\
\hline Opp. fruit per fruitbedr. (ha) & 12,9 & 16,5 & 8,5 & 11,4 \\
\hline Appels en peren per fruitbedr. (ha) & 10,3 & 15,6 & 7,7 & 10,2 \\
\hline Arbeidsbezetting per fruitbedr. b) & 1,8 & 2,1 & 1,9 & 2,2 \\
\hline Brutostandaardopbrengst per & 184 & 329 & 137 & 260 \\
\hline
\end{tabular}

fruitbedrijf $x € 1.000 \mathrm{c})$

a) Een bedrijf wordt gedefinieerd als fruitbedrijf als $2 / 3$ of meer van de totale brutostandaardopbrengst van het bedrijf uit het fruit komt; b)

Aantal mensen dat regelmatig meer dan 19 uur per week gedurende heel het jaar meewerkt op het fruitbedrijf (plukarbeid zit hier dus niet bij in; als deze plukarbeid omgerekend wordt naar de volledige jaar-arbeidstijd komen er gemiddeld 2 mensen per bedrijf bij); c) Gemiddelde berekende brutostandaardgeldopbrengst per fruitbedrijf $x € 1.000$

Bron: CBS, bewerkingen Wageningen Economic Research; normen gebaseerd op het areaal van het desbetreffende jaar en de gemiddelde omzet per ha van de vijf hiervoor gelegen boekhoudjaren. De norm voor 2015 is gebaseerd op de jaren 2008 tot en met 2012.

Gemiddeld groeide het gespecialiseerde fruitbedrijf de afgelopen tien jaar in oppervlakte van 10 tot ruim 15 ha. Ook de gemiddelde arbeidsbezetting nam de afgelopen tien jaar toe; van

1,8 arbeidsjaareenheid naar 2,1 per fruitteeltbedrijf (exclusief los personeel).

\subsection{Bedrijfseconomische situatie (landelijk)}

Door Wageningen Economic Research worden jaarlijks van circa 1.500 land- en tuinbouwbedrijven de bedrijfseconomische gegevens verzameld. Dit is een representatieve steekproef onder alle bedrijfstypen. Ook van de fruitteeltbedrijven wordt dit gedaan. Dit betrof over de jaren 2012 tot en met 2014 gemiddeld 36 bedrijven. In tabel 3.3 en 3.4 zijn de belangrijkste bedrijfseconomische kengetallen van deze bedrijven weergegeven. De kengetallen van deze bedrijven zullen gebruikt worden voor de specifieke bedrijfseconomische situatie van de fruitteeltsector in de gemeente Borsele en voor de bedrijven met een antihagelkanon.

Uit tabel 3.3 komt naar voren dat gemiddeld over de jaren 2012 tot en met 2014 voor appels 44 eurocent per kilo is betaald en 52 eurocent voor peren. Dit is dus gemiddelde over het gehele jaar. Direct na de pluk zijn doorgaans de prijzen lager en later in het bewaarseizoen hoger. Van jaar op jaar treden er echter grote verschillen op. Bedenk ook dat de kilo-opbrengsten van de plantopstand eveneens gemiddelden zijn. Op een normaal doorgaand fruitbedrijf zijn er ook altijd nieuwe plantopstanden die in ontwikkeling zijn. Voor een appelopstand duurt dit doorgaans 5 jaar en voor een perenopstand nog langer ( 7 jaar).

Uit tabel 3.3 blijkt dat gemiddeld de perenteelt beter rendeerde dan de appelteelt. De opbrengsten met aftrek van de specifiek toegerekende kosten waren voor de perenteelt ruim 3.500 euro per hectare hoger dan de teelt van appels. 
Tabel 3.3 geeft inzicht in het meer specifieke saldo van een teelt. Voor inzicht in het totale bedrijfsresultaat en de totale kosten dienen de algemene kosten zoals de pluklonen en de afschrijvingen op investeringen die gedaan zijn in tractoren, machines, hefmasten, spuiten, schuren, fust, opslagruimten, koelingskosten, etc. nog in mindering te worden gebracht.

Tabel 3.3 Opbrengsten en de directe toegerekende kosten van een gemiddelde hectare appels en peren over de jaren 2012 tot en met 2014. Gemiddeld per bedrijf in heel Nederland. Opbrengsten en kosten in euro's per hectare

\begin{tabular}{lrr} 
& Appels & 11,2 \\
Arealen (totaal ha) & 42.701 & 3,4 \\
\hline Kilo's per ha & 44 & 37.122 \\
\hline Gemiddelde prijs (eurocent per kilo) & 18.506 & 18.646 \\
\hline Opbrengsten gewas & 1.061 & 1.728 \\
\hline Aanwas & 500 & 265 \\
\hline Overige opbrengsten & 20.067 & 20.639 \\
\hline Totaal opbrengsten & 5.906 & 2.767 \\
\hline Toegerekende kosten, exclusief pluklonen & 14.161 & 17.872 \\
\hline Opbrengsten - toegerekende kosten & & \\
\hline
\end{tabular}

Bron: Bedrijveninformatienet en bewerkingen van Wageningen Economic Research.

Het verdiende totale gezinsinkomen op de fruitteeltbedrijven met appels en peren over de jaren 2012 tot en met 2014 was gemiddeld ruim $€ 51.000$ per jaar (tabel 3.4). Gemiddeld was er 1,33 regelmatig werkzame arbeidskracht aanwezig op deze bedrijven. Per gezinsarbeidskracht werd er dus gemiddeld bijna $€ 39.000$ per jaar verdiend.

Verder waren er op de bedrijven veel onregelmatige arbeidskrachten aanwezig (meestal plukarbeid, maar soms ook voor sorteren en snoeien). Dit is omgerekend 2,6 fulltime arbeidskrachten.

Als we kijken naar de verdiensten voor de ondernemer(s) per hectare dan kunnen deze over de jaren 2012 tot en met 2014 berekend worden op $€ 3.301$ per ha per jaar.

Tabel 3.4 Oppervlakte, arbeidsbezetting, opbrengsten, kosten en inkomens van het gemiddelde Nederlandse fruitbedrijf met appels en peren. Gemiddeld per jaar over de jaren 2012 tot en met 2014

\begin{tabular}{lr} 
Oppervlakte cultuurgrond ( $\mathrm{ha}$ ) & 15,6 \\
\hline Totaal arbeidsjaareenheden (aje) per bedr. & 3,97 \\
\hline Totaal aje per ha & 0,254 \\
\hline Onbetaalde aje (ondernemer + gezin) per bedrijf (aantal) & 1,33 \\
\hline Onbetaalde aje per ha (aantal) & 0,085 \\
\hline Betaalde aje per bedrijf (aantal) & 2,64 \\
\hline Betaalde aje per ha (aantal) & 0,169 \\
\hline Totaal opbrengsten fruit (x € 1.000) & 281 \\
\hline Totaal opbrengsten bedrijf (x€ 1.000) & 336 \\
\hline Totale opbrengsten per ha (euro) & 21.566 \\
\hline Totale betaalde kosten en afschrijvingen (x€ 1.000) & 285 \\
\hline Totale betaalde kosten en afschrijvingen per ha (euro) & 18.265 \\
\hline Gezinsinkomen uit bedrijf (in euro's) & 51.488 \\
\hline Inkomen per onbetaalde aje uit bedrijf (euro) & 38.713 \\
\hline Gezinsinkomen per hectare (euro) & 3.301 \\
\hline
\end{tabular}

Bron: Bedrijveninformatienet en bewerkingen Wageningen Economic Research.

De gemiddelde bedrijfsoppervlakte van de bedrijven in het Bedrijveninformatienet komt overeen met de gemiddelde bedrijfsoppervlakte van de fruitbedrijven met appels en peren in de gemeente Borsele. 


\subsection{Multiplier (spin-offeffecten) (landelijk)}

Op basis van door Wageningen Economic Research berekende recente data (Verhoog, 2016) over de afgelopen jaren is berekend dat over de jaren 2012 tot en met 2014 over elke euro toegevoegde waarde (inkomen) dat in de binnenlandse fruitproductie verdiend werd door aanverwante sectoren ook nog 53 eurocent indirect verdiend werd. Dit betrof 39 eurocent in de toelevering aan de binnenlandse fruitteelt (materialen, machines, diensten, etc.), 7 eurocent aan de verwerking van producten en 5 eurocent aan de distributie ervan.

Uit recente berekeningen rondom de werkgelegenheid (Verhoog, 2016) komt naar voren dat 1 arbeidsjaareenheid (aje) werkzaam in de binnenlandse primaire fruitsector goed is voor totaal 0,6 aje in de aanverwante sectoren. Dit betreft 0,42 aje in de toelevering, 0,12 aje in de verwerking en 0,06 aje in de distributie.

\subsection{Bedrijfseconomische situatie (gemeente Borsele)}

Als we de gegevens uit paragraaf 3.3 en 3.4 verbinden met de gegevens uit de voorgaande paragraaf 3.1 en 3.2 komen we voor de fruitteeltsector in de gemeente Borsele tot de kengetallen zoals die in tabel 3.5 en 3.6 weergegeven zijn.

De totale brutobedrijfsopbrengsten van de appels en peren op de bedrijven met fruit bedragen in de gemeente Borsele circa $30 \mathrm{mln}$. euro per jaar. Door de ondernemers en meewerkende gezinsleden wordt 4,6 mln. euro op deze bedrijven verdiend en door los personeel $7 \mathrm{mln}$. euro.

De totale directe werkgelegenheid in de gehele fruitsector wordt geschat op bijna

400 arbeidsjaareenheden en het totale direct verdiende inkomen op $13 \mathrm{mln}$. euro per jaar.

Tabel 3.5 Economische kengetallen van de fruitteeltsector in de gemeente Borsele in 2015

\begin{tabular}{|c|c|c|}
\hline & Factor & Totaal \\
\hline Ha fruit & & 1.668 \\
\hline Ha appels en peren & & 1.381 \\
\hline \multicolumn{3}{|l|}{ Op bedrijven met appels en peren: } \\
\hline Totaal Arbeidsjaareenheden & 1.381 ha $\times 0,254$ aje/ha & 350 aje \\
\hline Niet regelmatige arbeid (niet gezin) & $1.381 \times 0,169 \mathrm{aje} / \mathrm{ha}$ & 233 aje \\
\hline Bedrijfsopbrengsten appels en peren (euro's) & 1.381 ha $x € 21.566$ & $€ 29,8 \mathrm{mln}$. \\
\hline $\begin{array}{l}\text { Betaalde kosten en afschrijvingen appels en peren } \\
\text { (euro's) }\end{array}$ & 1.381 ha $x € 18.265$ & $€ 25,2 \mathrm{mln}$ \\
\hline \multicolumn{3}{|l|}{ Op overige bedrijven met fruit: } \\
\hline Zwarte bessen ( 256 ha) & 1 aje per 30 ha & 8 aje \\
\hline Ander fruit (31 ha) & 1 aje per ha & 31 aje \\
\hline Verdiende inkomens op deze bedrijven (schatting) & 39 aje $x$ circa $€ 35.000$ per jaar & $€ 1,4 \mathrm{mln}$. \\
\hline \multicolumn{3}{|l|}{ Totaal op bedrijven met fruit: } \\
\hline Verdiende inkomens & & $€ 13,0 \mathrm{mln}$. \\
\hline Totale directe werkgelegenheid fruitteeltsector & & 389 aje \\
\hline
\end{tabular}

Als de indirecte werkgelegenheid en inkomens die met de directe fruitteeltsector in Borsele samenhangen mee worden geteld dan komt de totale werkgelegenheid uit op 622 arbeidsjaren en de totaal verdiende inkomens op $20 \mathrm{mln}$. euro per jaar (tabel 3.6). 
Tabel 3.6 Inkomens en werkgelegenheid van de fruitteelt in Borsele en de daarmee samenhangende sectoren in 2015

Totale verdiende inkomens op bedrijven met fruit

Indirecte inkomens (hoofdstuk 3.4; multiplier x 0,53)

Totale verdiende inkomens

Totale werkgelegenheid op bedrijven met fruit (aje)

Indirecte werkgelegenheid in verwante sectoren

(hoofdstuk 3.4; factor 0,6)

Totale werkgelegenheid fruitcomplex
€ $13 \mathrm{mln}$.

$€ 6,9 \mathrm{mln}$

$19,9 \mathrm{mln}$. 389 aje

233 aje 622 aje

Buitenom de directe en indirecte werkgelegenheid in de fruitteeltsector zorgen de fruitboomgaarden er ook voor dat er verblijfsrecreanten en dagjesmensen (bloeiende boomgaarden in het voorjaar) naar het gebied komen. De Zak van Zuid Beveland is mede hierdoor een aantrekkelijk landschap voor toeristen. Veel recreanten komen mede hierdoor naar het gebied. Dit zorgt voor enige tientallen arbeidsjaren werk op een aantal campings en horecagelegenheden. 


\section{$4 \quad$ Economisch belang fruitteeltbedrijven met een antihagelkanon}

De 23 bedrijven met een antihagelkanon zijn gemiddeld in bedrijfsoppervlakte een derde groter dan de gemiddelde fruitbedrijven in de gemeente Borsele en in het Bedrijveninformatienet van Wageningen Economic Research. Aangenomen mag worden dat de omzetten en kosten van de bedrijven met een antihagelkanon ook een derde hoger zullen liggen. Ook de arbeidsbezetting ligt hoger.

De totale bedrijfsopbrengsten uit de fruitteelt van de bedrijven met een antihagelkanon kunnen op basis van het areaal ( 485 ha; 228 ha appels, 247 peren en 10 ha kersen) en de bedrijfsopbrengsten per ha ( $€ 20.067 /$ ha voor appels en $€ 20.639 /$ ha voor peren) geschat worden op circa $10 \mathrm{mln}$. euro per jaar (tabel 4.1). Dit komt overeen met een geldopbrengst van gemiddeld $€ 435.000$ per bedrijf.

Bij de interpretatie van deze bedrijfsopbrengsten en de kengetallen uit tabel 4.1 dient het volgende te worden opgemerkt: bij de berekeningen van de geldopbrengsten op de bedrijven met een antihagelkanon is gebruik gemaakt van de arealen op deze bedrijven en zijn deze vermenigvuldigd met de landelijke gegevens van de fruitbedrijven uit het Bedrijveninformatienet. In dit landelijke informatienet zitten vrijwel geen fruitbedrijven met een antihagelkanon. Door het gebruik van het antihagelkanon kan er op de bedrijven met een antihagelkanon minder hagelschade zijn geweest en kunnen dus grotere geldopbrengsten per hectare zijn behaald dan landelijk het geval is geweest. De bedrijfseconomische kengetallen zoals die in tabel 4.1 weergegeven zijn eerder een onderschatting dan een overschatting van de werkelijkheid op de bedrijven met antihagelkanon in Borsele.

De totale werkgelegenheid op de bedrijven met een antihagelkanon bedraagt omgerekend totaal 126 arbeidsjaren. Dit zijn 56 arbeidsjaren gezinsarbeid en 70 omgerekende arbeidsjaren los personeel (plukken, maar ook soms voor sorteren en snoeien). Verder creëren de bedrijven met een antihagelkanon aan indirecte werkgelegenheid (toelevering, verwerking, distributie, en dergelijke) voor 76 arbeidsjaren werk, zodat de totale werkgelegenheid die met de bedrijven met een antihagelkanon samenhangt berekend kan worden op 200 arbeidsjaren.

De verdiende inkomens op de bedrijven met een antihagelkanon bedragen voor de gezinnen totaal 1,6 mln. euro en voor het losse personeel circa 2,1 mln. euro. Gemiddeld per bedrijf komt dit neer op een arbeidsinkomen uit het bedrijf van $€$ 69.600. Op het gemiddelde bedrijf werken gemiddeld 2,4 mensen regulier, zodat dit neer komt een gemiddeld inkomen van $€ 28.600$ per jaar per reguliere arbeidskracht. Aan indirecte inkomens (toelevering, verwerking, distributie) wordt circa $2 \mathrm{mln}$. euro per jaar verdiend, zodat het totale inkomen dat samenhangt met de bedrijven met een antihagelkanon berekend kan worden op 5,7 mln. euro per jaar. 
Tabel 4.1 Kenmerken van de fruitbedrijven met een antihagelkanon

\begin{tabular}{|c|c|c|c|}
\hline & Alle bedrijven & Gemiddeld per bedrijf & $\begin{array}{l}\text { Gemiddeld per } \\
\text { arbeidsjaareenheid }\end{array}$ \\
\hline Aantal bedrijven & 23 & & \\
\hline Oppervlakte onder antihagelkanon (ha) & 453 & 19,7 & \\
\hline Aantal arbeidsjaareenheden (regulier) & 56 & 2,43 & \\
\hline Aantal arbeidsjaareenheden (totaal) & 126 & 5,47 & \\
\hline Bruto-opbrengsten fruit (euro's/jaar) & $10 \mathrm{mln}$. & 435.000 & \\
\hline Inkomen uit bedrijf voor gezinnen & $1,6 \mathrm{mln}$. & 69.700 & 28.600 \\
\hline Inkomens losse arbeidskrachten & $2,1 \mathrm{mln}$. & 91.300 & 30.000 a) \\
\hline
\end{tabular}

a) Dit is een omgerend jaarloon, dat feitelijk door circa 10-15 mensen behaald wordt die meestal 3 tot 6 weken komen plukken.

Ondanks dat er economisch veel in de fruitteeltbedrijven omgaat met hoge bruto-geldomzetten en veel werkgelegenheid worden er de afgelopen jaren gemiddeld geen hoge inkomens op de bedrijven zelf verdiend. Dit betekent ook dat men met een geringe tegenslag door weersomstandigheden of een kleine daling in de opbrengstprijs van fruit gelijk een lager inkomen heeft. Men is wat dit betreft dus kwetsbaar in zijn bedrijfsvoering en kan weinig bedrijfsrisico's lopen. In dit licht gezien is het belangrijk dat men de risico's die men in de hand heeft reduceert. 


\section{Economische impact van een hagelbui}

Fruit moet tegenwoordig van topkwaliteit zijn. Klasse 1 fruit wordt redelijk betaald, maar fruit waar wat aan mankeert wordt bij levering aan de veiling of aan handelaren in een lagere klasse ingedeeld. Klasse 2 fruit brengt hoegenaamd niets meer op. Door hagelbuien in het voorjaar en de zomer treden er door de inslag van de hagelkorrels beschadigingen op aan het dan hangende en zich ontwikkelende fruit. Hagelschade kan zich op een gedeelte van een perceel voordoen of op een heel perceel, maar het kan ook het hele bedrijf treffen. De economische impact op het bedrijf van een hagelbui is ook afhankelijk van het aantal keren dat hagelbuien het bedrijf treffen.

\section{Hagelschade op een perceel}

\section{Beperkte schade}

Als er aan een boom minder dan 15-20\% beschadigde appels of peren hangen dan kan men met het plukken nog rekening houden met dit feit. Men plukt ze niet of men laat de beschadigde appels of peren na het plukken gelijk op de grond vallen in plaats van in de kist. Dit vereist nauwkeurigheid bij het plukken en is meer werk (plukkosten worden hoger; deze gaan van ongeveer 10 cent per kilo naar ongeveer 12 cent per kilo).

\section{Grote schade}

Als er aan een boom meer dan 15-20\% beschadigde appels of peren hangen dan is het niet meer mogelijk om de goede appels en peren uit te zoeken met de pluk. Het is dan onbegonnen werk geworden om het fruit in de eerste klasse te krijgen. Voor lagere klasse dan klasse 1 zijn de prijzen tegenwoordig zo laag dat daar niet voor geplukt kan worden. De industrie betaalde bijvoorbeeld in 2016 circa 10 eurocent per kilo voor verhageld fruit (ongeveer de plukprijs), maar soms is dit ook veel minder ( 3 eurocent). Een heel enkele keer wordt iets meer betaald (tot 15 eurocent).

De directe geldopbrengsten van het fruit van een perceel dat geheel getroffen wordt dalen van gemiddeld $€ 18.500$ per hectare naar circa $€ 3.500$ per ha (industriefruit; hiervan moeten nog de pluklonen van af). De verliezen kunnen hoger zijn als de fruitopstand in volle wasdom is. Op het desbetreffende perceel wordt een bedrijfseconomisch verlies geleden; de kosten voor het perceel zijn wel gemaakt en opbrengsten zijn er niet.

\section{Hagelschade op het hele bedrijf}

Soms worden meerdere percelen getroffen door een hagelbui. Maar het komt ook voor dat een heel bedrijf getroffen wordt. De opbrengsten van het fruit dalen dan navenant. Als een heel bedrijf getroffen wordt door een hagelbui en als de pluklonen betaald zijn dan resteert er niets voor andere kosten en werkzaamheden. Als een hagelbui het hele bedrijf treft, dan wordt er verlies geleden (alle kosten zijn gemaakt en opbrengsten zijn er niet). Het inkomen is in zo'n jaar sterk negatief. Dit kan vele tienduizenden euro's zijn, maar kan ook oplopen tot meer dan honderd duizend euro's. 


\section{Resultaten interviews ${ }^{3}$}

In het onderzoek zijn in november 2016 kwalitatieve interviews afgenomen bij de betrokken fruitbedrijven van 6 kanonnen om in beeld te brengen hoe zij de effecten en werking van het antihagelkanon ervaren. In totaal waren er 19 bedrijven bij de interviews betrokken.

De interviews hebben plaats gevonden rond de volgende vragen:

1. Hoe lang heeft $\mathrm{u}$ het hagelkanon?

2. Zijn er nog hagelverzekeringen afgesloten? Wat zijn de eigen risico's daarbij?

3. Wat zijn de hagelschades geweest in de afgelopen jaren? (Zo ver mogelijk terug gaan in de tijd)

4. Welke delen van het bedrijf zijn getroffen?

5. Wat waren de totale schades per jaar als er schade was? (Uitgedrukt in euro's)

6. Welk deel is door een eventuele verzekering gedekt en wat was het eigen risico?

7. Hoe waren de schades in de jaren voorafgaand aan het gebruik van het hagelkanon?

8. Werking en duur van het hagelkanon.

9. Algemene opinie waarde van het antihagelkanon.

10. Hoe is de bedrijfsontwikkeling geweest de afgelopen jaren? (toename fruitareaal?

11. Is er op het bedrijf een opvolger (al of niet doorgaande bedrijven)?

12. Andere zaken die aan bod komen.

De verslaglegging van deze vragen in dit hoofdstuk is kwalitatief wat een duiding geeft van wat de telers met een antihagelkanon zelf ervaren hebben. Het geeft een indruk gebaseerd op de mening van de telers. Kwantitatieve data voor het uitvoeren van een dergelijke analyse zijn niet beschikbaar.

Tijdstip van plaatsing

Vrijwel alle hagelkanonnen zijn in 2007 geplaatst. Dit nadat in de drie jaren daarvoor veel hagelschade was geweest. Eén kanon is in 2008 geplaatst en één van de negen kanonnen staat er nu vier jaar. De plaatsing is voort gekomen via contacten met Belgische fruittelers net over de grens (die ook hun fruit veilden op de Nederlandse fruitveiling Fruitmasters in Geldermalsen).

\section{Hagelverzekeringen}

Bijna alle bedrijven hebben geen hagelverzekering meer afgesloten. Dit met uitzondering van twee bedrijven: één met een hoog eigen risico en één bedrijf heeft de afgelopen vier jaar een hagelverzekering afgesloten vanwege de elk jaar onzekere situatie of de milieuvergunning voor het hagelkanon voor het komende groeiseizoen wordt verleend.

Hagelschade in de afgelopen tien jaar

In het algemeen is de hagelschade de afgelopen jaren beperkt geweest. Dikwijls was er als er schade was dit aan de buitenkant van het bereik van het kanon. Het bereik is een straal van ongeveer 500 meter vanaf het apparaat. De totale bereikte oppervlakte van één antihagelkanon is te berekenen op 78 ha. In werkelijkheid is het bereik geen cirkel maar door de bijkomende wind een eivorm.

De inventarisatie leverde het volgende beeld op:

- Een derde van de bedrijven heeft de afgelopen tien jaar geen hagelschade gehad. De andere bedrijven hadden in de afgelopen jaren beperkte schade. Dit betrof meestal schade aan de rand van de werkingssfeer van het kanon of aan de westkant van de werkingssfeer; de meeste onweersbuien komen uit het zuidwesten of westen. Aan de oostkant van de werkingssfeer van het kanon is de werking daardoor meestal beter. Bij onweersbuien zonder veel wind is de werking van het kanon goed.

- Bij heftige buien zijn er op enkele bedrijven beperkt grote hagelstenen naar beneden gekomen, maar geen kleine hagelstenen. De schade was beperkt: 2 à 3\% van de appels/peren was

\footnotetext{
3 De in totaal 9 antihagelkanonnen zijn allemaal van hetzelfde type en van dezelfde leverancier.
} 
beschadigd, maar dit fruit kon bij de pluk al uitgezocht worden. Bij één teler is er een heftige bui geweest met circa $10 \%$ schade; de oogst was nog wel te plukken. Eén teler heeft op een perceel aan de rand van het bereik van het kanon een schade gehad van $25 \%$.

- Door de werking van het antihagelkanon komen potentiële hagelbuien niet tot verdere ontwikkeling. Soms komt de potentiële hagel als sneeuw naar beneden of is er beperkte schade (meestal aan de rand van de werkingssfeer van het antihagelkanon). Sommige fruittelers hebben die sneeuw ook geconstateerd in plaats van hagel.

- De enkele keren met beperkte schade was er meestal wat aan de hand: Eén keer was het kanon te laat aangezet en een andere keer veranderde de bui ineens van richting.

De overheersende mening is dat de hagelkanonnen prima werk doen en schade voorkomen en beperken. $\mathrm{Er}$ is slechts een geringe schade geweest in de afgelopen tien jaar. Alleen bij heftige onweersbuien (zoals in Limburg in 2016) met grote hagelstenen is de mening dat men dan ook wel schade zal hebben. De schade wordt dan wel lager ingeschat dan zonder een kanon.

Enkele bedrijven hebben ook fruitpercelen die elders liggen: enkele kilometers verderop buiten de werking van een antihagelkanon. Op deze percelen is de afgelopen jaren wel hagelschade geweest, soms meerdere jaren achter elkaar. Ook is er een teler die een perceel fruit heeft liggen dicht bij een voormalige locatie van een hagelkanon van een teler die gestopt is. Toen het kanon nog werkte hadden ze geen hagelschade.

Niet alle grond binnen het bereik van het antihagelkanon is fruitteeltgrond; ook akkerbouwgrond ligt hier soms in. Ook daar is geen of minder hagelschade. Hetzelfde geldt voor de in het werkingsgebied van het antihagelkanon gelegen woningen en bedrijfsgebouwen; ook zij hebben minder last van hagelschade.

Welke delen van het bedrijf hebben hagelschade?

Als er hagelschade op de bedrijven optreedt dan is dit meestal op fruitpercelen die aan de rand van de werkingssfeer van het kanon liggen, meestal meer aan de westkant dan aan de oostkant (bij een doorgaans overheersende windrichting vanuit het westen of zuidwesten). Op fruitpercelen die men elders heeft, buiten de werkingssfeer van de antihagelkanonnen, is regelmatig hagelschade die groter is dan op de percelen bij de antihagelkanonnen.

Schades per jaar sinds het antihagelkanon

Bijna alle bedrijven hebben geen of hooguit in een enkel jaar enkele procenten ( 2 à $3 \%$ ) schade gehad. Als er al schade was dan was deze dikwijls beperkt. Bij deze beperkte schade was het fruit nog wel te plukken; bij de pluk konden de appels of peren met hagelschade eruit gehaald worden. Men kon in dezelfde klasse blijven bij de verdere commercialisering van het fruit.

Bij de bedrijven die een enkele keer meer schade hebben gehad was het vooral schade aan de rand van het werkingsgebied van het kanon. Dit met uitzondering van één heftige bui met alleen grote hagelstenen (geen kleinere stenen); de schade was toen 10\%, maar het perceel was nog wel te plukken.

Schades in de jaren voor het gebruik van het antihagelkanon

In de jaren voor de aanschaf van het antihagelkanon hadden de bedrijven vaker hagelschade.

Per antihagelkanon zijn de volgende opmerkingen gemaakt:

- 'We hadden hier vroeger om de drie jaar schade van licht tot matig; in 2006 is hier alles compleet verhageld.'

- 'Eens in de vijf à zes jaar hadden we hier hagelschade. De laatste tien jaar hebben we helemaal geen schade gehad.'

- 'Tussen 2003 en 2008 hebben we drie keer schade gehad, waarvan één redelijk ernstig.'

- 'Om het jaar hadden we schade. Dit jaren aan een stuk (sinds 1984). Soms ook twee keer per jaar. Vooral vanaf 1990 waren er duidelijk meer hagelbuien.' 
- 'I $k$ had veel schade in 2005 en 2006. Meer dan de helft van de oogst ging in de kroet (mindere kwaliteit, alleen gebruikt voor appelmoes).'

- 'In de drie jaren voor aanschaf van het antihagelkanon zijn we in twee jaar compleet verhageld. Ook in de jaren daarvoor was er regelmatig veel schade.'

Door vrijwel iedereen wordt opgemerkt dat als je tegenwoordig hagelschade hebt dit ernstiger is dan vroeger. De eisen bij de handel, veiling, exporteur, retailer en consument zijn strenger geworden. Voor klasse 1 fruit wordt redelijk tot goed betaald, maar klasse 2 brengt weinig op. Echt verhageld fruit is niet meer te sorteren en is uiteindelijk alleen geschikt voor appelmoes. Dit is al het geval als $20 \%$ van je appels/peren hagelplekken hebben.

Werking en duur van het antihagelkanon

Bij kans op onweer wordt door de meeste telers op de site van buienradar (tien minuten vertraging) of de meer nauwkeurige Engelse site 'realtimelightning' ${ }^{4}$ de gang van het onweersfront in de gaten gehouden (twee seconden vertraging). Men brengt elkaar op de hoogte hiervan via de telefoon en voert overleg over het aanzetten van het antihagelkanon. Als de bui er aankomt wordt 20 minuten tot een half uur van tevoren het apparaat aangezet. De meesten doen dit elektronisch op afstand.

Elke zeven seconden wordt er door het kanon een drukgolf de lucht ingestuurd waardoor de hagel niet kan ontstaan of de waterdruppel zich niet kan ontwikkelen tot hagel korrel (waarschijnlijk door menging van de lagere warmere lucht van circa 30 graden met de hogere koude luchtlagen met circa - 30 graden; de druppels worden op en neer geslingerd; soms komt er geen hagel naar beneden maar sneeuw).

Gemiddeld staat het apparaat zeven dagen per jaar aan (een enkele keer meerdere keren per dag). De variatie is van 5 tot 15 dagen per jaar. Meestal staat het apparaat 20-30 minuten aan. De totale gemiddelde tijd dat het apparaat aanstaat is 6 uur per jaar (variatie van 4-8 uur). In 2016 was dit relatief weinig. In 2015 relatief veel. De meeste onweersbuien zijn tussen 17.00 en 22.00 uur. 's-Nachts is dit doorgaans veel minder (circa een vijfde van de tijd).

Op de site 'realtimelightning' is het mogelijk om exact de koers van een onweersbui met bijbehorende lichtflitsen te volgen. Hier kun je ook beelden in de tijd van maken. Door de fruittelers is verschillende keren vastgelegd, dat buien die vanaf Noord-Frankrijk via België naar Zeeland en verder naar het noorden trokken hun activiteit boven de Zak van Zuid Beveland verminderden. In bijlage 1 bij deze nota is een opname hiervan weer gegeven. Er waren in de hele strook lichtflitsen te zien behalve boven de gemeente Borsele (er waren geen ontladingen te zien). De opnamen bevestigen volgens de geïnterviewde fruittelers dat dit door de werking van de antihagelkanonnen komt. Er zijn naast de in bijlage 1 weergegeven bewaarde opname ook nog tien andere opnames bewaard van onweersbuien over de jaren 2006 tot en met 2015, warop te zien is dat de werking van de onweersbui minder wordt of dooft boven de gemeente Borsele.

Algemene opinie en waarde van het antihagelkanon

Het antihagelkanon wordt als waardevol beschouwd. 'Het kost wat, maar dan heb je ook wat'. ledereen is positief, omdat 'het apparaat zeer goed werkt'. Men is het er over eens dat er binnen de werkingssfeer van het antihagelkanon minder hagelschade voor komt. Zeker als men dit vergelijkt met andere percelen fruit die wat verder van de huispercelen liggen. Daar heeft men regelmatig hagelschade.

Bedrijfsontwikkeling in de afgelopen jaren Veel bedrijven hebben de afgelopen jaren hun bedrijfsareaal uitgebreid. Bedrijven waar de zoon mee is gaan meewerken hebben dit flink gedaan. De geïnterviewde bedrijven hebben nu circa 40 ha meer fruit dan 10 jaar geleden. Er vindt nog steeds door sommigen een omschakeling plaats van akkerbouwgrond naar fruitteelt. Ook heeft men voortdurend plantopstanden vernieuwd en heeft er een omschakeling plaats gevonden van minder appels naar meer peren.

4 https://www. lightningmaps.org 
Continuïteit bedrijven

Op de bedrijfshoofden ouder dan 50 jaar is op vrijwel alle bedrijven een opvolger aanwezig. Sommige bedrijven hebben meer dan één opvolger. Ook zijn er veel bedrijven waar de bedrijfshoofden tussen de 30 en 50 jaar zijn. Normaal gesproken kan er van uitgegaan worden dat alle bedrijven onder de huidige omstandigheden over zo'n tien jaar zeker nog zullen bestaan.

Andere zaken uit de interviews

Het antihagelkanon wordt door de betrokken fruittelers als waardevol beschouwd. Men vindt het een onmisbaar apparaat in de totale bedrijfsvoering. Het alternatief dat door tegenstanders van het kanon aangedragen wordt, het zogenaamde 'stille kanon' wordt niet als een serieus alternatief gezien. Dit omdat het met geluidsgolven werkt en deze een ander werkingsgebied hebben. Er is tot nu toe geen bewijs dat dit zou kunnen werken.

Ook het alternatief van een hagelnet wordt door de betrokken fruittelers niet als een werkbaar alternatief gezien: in Zeeland zal dit door de meer hevige wind stevig moeten zijn. Goed materiaal is vereist en een extra hoog windscherm. De kosten hiervan bedragen circa $€ 25.000$ per ha. Deze investering is voor veel bedrijven te hoog en komt boven op de toch al hoge kosten voor grond en plantopstanden. 


\section{$7 \quad$ Slotbeschouwing}

In dit onderzoek zijn de 23 bedrijven met een antihagelkanon (totaal 9) in de gemeente Borsele nader beschouwd. In de gemeente Borsele staat het merendeel van de antihagelkanonnen van Nederland. In België staan er meer. De fruitbedrijven met een antihagelkanon in Borsele zijn doorgaans groter dan de andere fruitbedrijven in de gemeente en dan landelijk het geval is. Ook werken er meer mensen.

De totale directe en indirecte werkgelegenheid die samenhangt met bedrijven met een antihagelkanon is ongeveer 200 arbeidsjaren. De verdiende totale arbeidsinkomens zijn voor de fruitbedrijven met een antihagelkanon 3,7 mln. euro per jaar en voor de daarmee samenhangende indirecte sectoren $2 \mathrm{mln}$. euro per jaar. Samen dus 5,7 $\mathrm{mln}$. euro. De directe brutobedrijfsopbrengsten op de fruitbedrijven zijn ongeveer $10 \mathrm{mln}$. euro per jaar. Voor de fruitteeltsector in de hele gemeente Borsele liggen deze kengetallen ongeveer drie keer zo hoog.

De fruitteeltsector is economisch gezien een belangrijke bedrijfstak die voor werkgelegenheid en inkomen zorgt. Dit zowel in de gemeente zelf als daarbuiten in de aan de fruitteelt verwante en afhankelijke sectoren. De antihagelkanonnen worden door ongeveer 30\% van de fruitteeltbedrijven in de gemeente Borsele gebruikt. Dit betreft 35\% van het totale areaal appels en peren.

Het antihagelkanon is volgens de geïnterviewden in dit onderzoek belangrijk om het bedrijfsrisico van hagelschade te voorkomen of in ieder geval te beperken. Percelen met hagelschade leveren doorgaans weinig tot niets op. Als een heel bedrijf ernstig getroffen wordt door hagelschade dan kan het verlies op het bedrijf op lopen van vele tienduizenden euro's tot meer dan honderd duizend euro.

De fruittelers met een antihagelkanon bedrijven zijn erg tevreden over het gebruik van het antihagelkanon en zijn er zelf van overtuigd dat het goed werkt. Uit dit onderzoek blijkt dat er aanwijzingen zijn dat dit zo zou kunnen zijn. Als dit zo zou zijn dan is het antihagelkanon niet alleen een apparaat dat in de fruitteelt hagelschade kan voorkomen, maar dat zou ook breder ingezet kunnen worden ter voorkoming van hagelschade bij andere bedrijven en particulieren. Hierbij kan gedacht worden aan andere gewassen (hoogwaardige opengrond tuinbouwteelten en

akkerbouwgewassen), woningen, bedrijfsgebouwen, tuinbouwkassen, huizen en auto's. Ook in de regionale pers is hier uitgebreid aandacht aan besteed (PZC, 12 september 2011). Een nauwkeurig en breed gedragen onderzoek naar het voorkomen van hagelschade door middel van het antihagelkanon is wenselijk. 


\section{Bijlage 1 Momentopname van de onweersbui van 28 augustus 2016, 6.53 uur}

De sheet is via de computer uitgeprint vanaf de website: www. lightningmaps.org op 28 augustus 2016 om 6.53 uur. Er zijn ook vergelijkbare opnames beschikbaar van tien andere onweersbuien in de periode 2006 tot en met 2015.

Op de website en uitgeprinte sheet in deze bijlage is de loop van deze onweersbui te volgen. Deze is vanaf Noord-Frankrijk en België via Zeeland naar Zuid- en Noord-Holland getrokken (richting zuidwest-noordoost). De onweersbui bereikte Zuid- en Noord-Holland in het uur na 6.53 uur. Daar zijn ook opnames van, maar hier niet weer gegeven. Op het moment van uitprinten was de bui het actiefst boven Tholen. Elk rood rondje daar geeft een actuele lichtflits aan. Dit met een vertraging van 2 seconden. De minuten hieraan voorafgaand tot een uur hiervoor zijn er lichtflitsen geweest in de omgeving van Terneuzen en ten noorden van Gent. Dit zijn de gele rondjes.

De opnames van de lichtflitsen worden op de website één uur bewaard. Als ze er bijna afgaan worden de lichtflitsen als bruin weer gegeven. Dit is op de kaart te zien in België bij Deinze en Waregem. Daar zijn dus de lichtflitsen van dezelfde onweersbui die daar een uur daarvoor is geweest.

Duidelijk is op de foto te zien dat de onweersbui boven de gemeente Borsele (de Zak van Zuid Beveland) nauwelijks of geen activiteit liet zien. In de andere gebieden in de richting van het onweersfront weer wel. De opname bevestigt het beeld dat er aanwijzingen zijn dat dit door de werking van de antihagelkanonnen zou kunnen komen.

De computerfoto is gemaakt door en afkomstig van André Raas, fruitteler met een antihagelkanon in Heinkenszand (gemeente Borsele). 


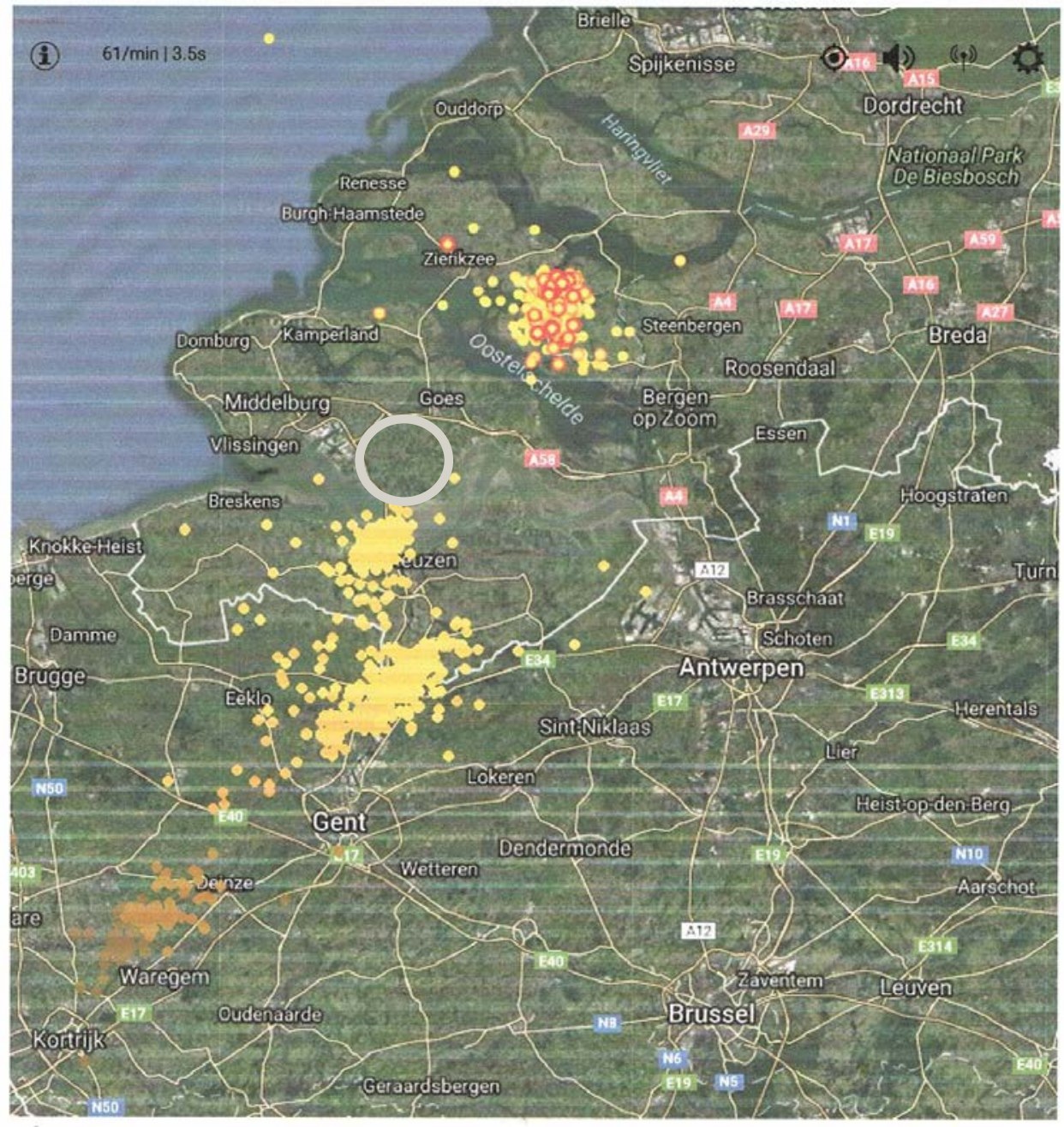

Figuur B.1 De cirkel op de kaart duidt de gemeente Borsele (de Zak van Zuid Beveland) aan, waar de onweersbui nauwelijks of geen activiteit liet zien 
Wageningen Economic Research Postbus 29703

2502 LS Den Haag

T 0703358330

E communications.ssg@wur.nl

www. wur. nl/economic-research

Wageningen Economic Research NOTA

2017-034
De missie van Wageningen University \& Research is 'To explore the potential of nature to improve the quality of life'. Binnen Wageningen University \& Research bundelen Wageningen University en gespecialiseerde onderzoeksinstituten van Stichting Wageningen Research hun krachten om bij te dragen aan de oplossing van belangrijke vragen in het domein van gezonde voeding en leefomgeving. Met ongeveer 30 vestigingen, 5.000 medewerkers en 10.000 studenten behoort Wageningen University \& Research wereldwijd tot de aansprekende kennisinstellingen binnen haar domein. De integrale benadering van de vraagstukken en de samenwerking tussen verschillende disciplines vormen het hart van de unieke Wageningen aanpak. 



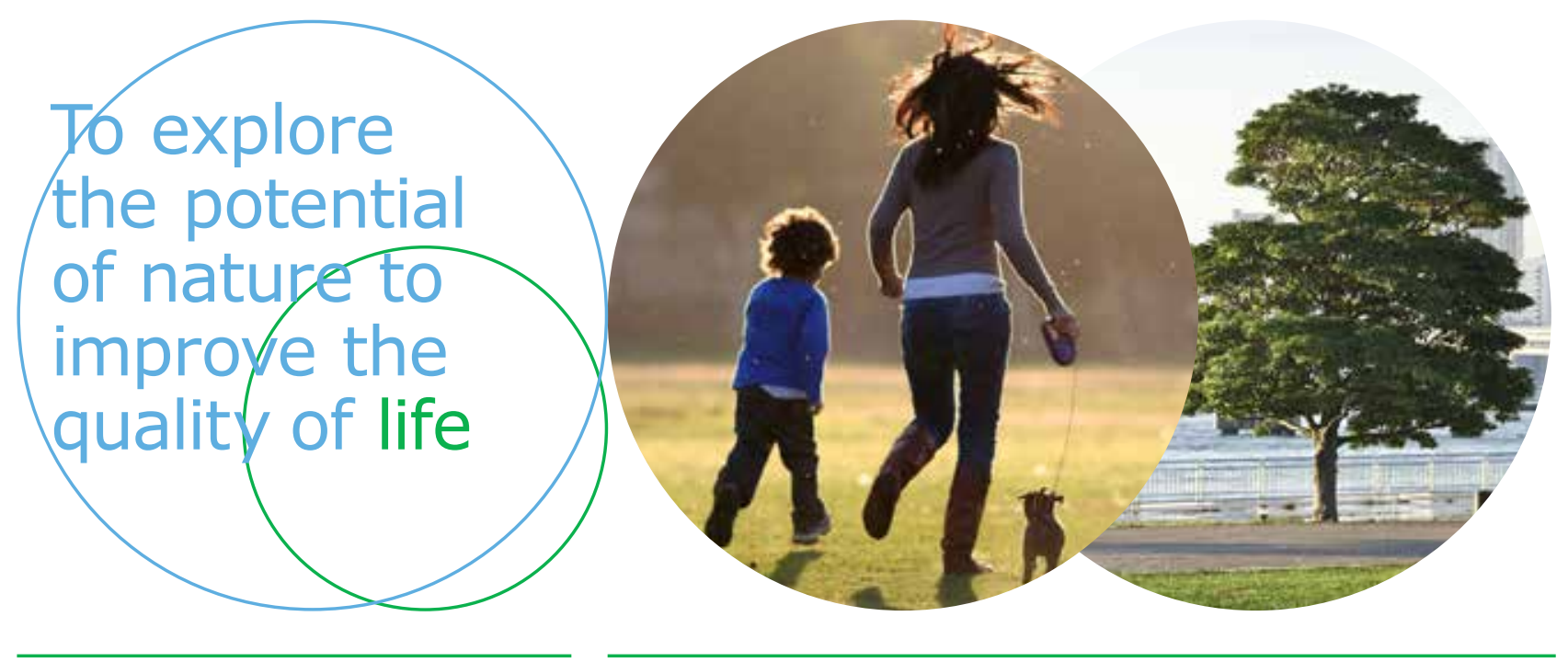

Wageningen Economic Research Postbus 29703

2502 LS Den Haag

E communications.ssg@wur.nl

$\mathrm{T}+31(0) 703358330$

www.wur.nl/economic-research

Nota 2017-034
De missie van Wageningen University \& Research is 'To explore the potential of nature to improve the quality of life'. Binnen Wageningen University \& Research bundelen Wageningen University en gespecialiseerde onderzoeksinstituten van Stichting Wageningen Research hun krachten om bij te dragen aan de oplossing van belangrijke vragen in het domein van gezonde voeding en leefomgeving. Met ongeveer 30 vestigingen, 5.000 medewerkers en 10.000 studenten behoort Wageningen University \& Research wereldwijd tot de aansprekende kennisinstellingen binnen haar domein. De integrale benadering van de vraagstukken en de samenwerking tussen verschillende disciplines vormen het hart van de unieke Wageningen aanpak. 